\title{
KNOWLEDGE, ATTITUDE, PERCEPTION OF COVID-19 PREVENTION PRACTICES AMONG RESIDENTS IN SELECTED LOCAL GOVERNMENT AREAS IN LAGOS STATE NIGERIA
}

\author{
Opatola Kikelomo O. ${ }^{1}$, Professor Moturanyo F. Olanrewaju ${ }^{2 *}$ \\ and Professor Atulomah N.O. ${ }^{2}$
}

${ }^{1}$ Department of Public Health, School of Public and Allied Health, Babcock University, IlishanRemo, Ogun State, Nigeria. E-mail: kikelomo.opatola@gmail.com; Tel no: +2348022366666

2Email: olanrewajum@babcock.edu.ng

3Email: atulomahn@babcock.edu.ng

Cite this article:

Opatola K.O., Moturanyo F.O, Atulomah N.O. (2021), Knowledge, Attitude, Perception of Covid-19 Prevention Practices Among Residents in Selected Local Government Areas in Lagos State Nigeria. African Journal of Biology and Medical Research 4(3), 17-38. DOI: 10.52589/AJBMRKBTRCCBU.

\section{Manuscript History \\ Received: 6 May 2021 \\ Accepted: 31 May 2021 \\ Published: 19 June 2021}

Copyright (C) 2020 The Author(s). This is an Open Access article distributed under the terms of Creative Commons Attribution-NonCommercialNoDerivatives 4.0 International (CC BY-NC-ND 4.0), which permits anyone to share, use, reproduce and redistribute in any medium, provided the original author and source are credited.
ABSTRACT: Background: COVID-19 has no effective cure, yet early recognition of symptoms and timely seeking of supportive care and preventive practices enhance recovery from the illness and combat the spread of the virus. To reduce the risk of transmission in the community, individuals should be advised to wash hands diligently, practice respiratory hygiene (cover their cough), avoid crowds and close contact with ill individuals (WHO,2019). This study was a cross sectional descriptive study carried out in January, 2021 designed to assess the knowledge, attitude, perception of covid-19 prevention practices among residents in selected local government areas in Lagos State Nigeria. The knowledge obtained from this research should act as a framework for educating the population about the triggers, modes of infection and, most specifically, disease prevention. Methods: The data was collected and analyzed using the statistical package of social (SPSS) version 28. Descriptive statistics and inferential statistics were used. Inferential statistic that was used is Chi-square and was adopted in testing the hypothesis at 0.05 level of significance. Four hundred and twenty questionnaires (420) were administered, and four hundred were completely and correctly filled. The response rate was $95.2 \%$. Results: The mean age of the respondents was $38.43 \pm 16.4$ years. The ages of the majority 118 (29.5\%) of the respondents, fell within the 30 to 39 years age range. Most 251(62.8\%) of the respondents were female while less than half 158(39.5\%) of the respondents were Muslims. More than half 208(52.0\%) of the respondents were married. Few $135(33.8 \%)$ of the respondents had tertiary education, with less than half 151(37.8\%) of the respondents without formal education. Most $174(43.4 \%)$ of the respondents are Artisans. More than half 241(60.3\%) of the respondents had fair knowledge about COVID19, with 159(39.8\%) of the respondents having good knowledge. Most $279(69.8 \%)$ of the respondents had low perception of COVID19 prevention while 121(30.2\%) of the respondents had high perception. All 400(100\%) of the respondents had negative attitudinal disposition towards COVID19 prevention. Slightly half 262(67.8\%) of the respondents had poor prevention practices, while 198(49.5\%) of the respondents had good prevention practices. Conclusion: This study provided a comprehensive look at the knowledge, attitude and perception of COVID19 prevention practices among residents of 
selected local government areas in Lagos Nigeria. The participants had a high level of knowledge about the virus and good practice towards using protective measures, which is significant towards controlling the spread of the virus. But the attitudinal disposition of the respondent's was negative; this could be because of inadequate information regarding the virus. This study recommends developing informative COVID-19 related campaigns, and providing necessary protective mask and hand sanitizers for the residence of this community. Effective health education campaigns aimed at enhancing attitude of COVID-19 are therefore desperately needed to promote positive mindset and maintain appropriate preventive practices and health campaigns should be more focused on practices such as regular hand-washing with soap and water and social distancing, which protect against transmission of COVID-19 among community members irrespective of their sex.

KEYWORDS: COVID 19, LGA, SARS-CoV-2, NCDC, WHO

\section{INTRODUCTION}

Novel-coronavirus disease is currently a global health threat and public health emergency of international concern. The severe acute respiratory syndrome outbreak that was linked to coronavirus (SARS-COV) was first reported in 2003.

It was by far the largest outbreak of a typical pneumonia since the SARS outbreak. Subsequently, the spread of the virus has shown exponential growth and spread to all continents and received a unique name by COVID-19 from the World Health Organization (Cao et al, 2019).

On January 30, 2020, the World Health Organization declared that COVID-19 is a pandemic disease (Wang et al, 2020). As of December 2019, until February, 2021, the pandemics registered 119.8 million cases and 2.6 million deaths in the world. On the 4th of March 2021, 709 new confirmed cases and 12 deaths were recorded in Nigeria (Nigeria center for disease control, 2020). Till date, 157671 cases have been confirmed, 136335 cases have been discharged and 1951 deaths have been recorded in 36 states and the Federal Capital Territory. In Nigeria, the first case of COVID-19 was discovered on February 27, 2020 in Lagos State, in an Italian tourist on a business trip to the Ewekoro cement plant in Ogun State.

COVID-19 has no effective cure, yet early recognition of symptoms and timely seeking of supportive care and preventive practices enhance recovery from the illness and combat the spread of the virus. The symptoms of COVID-19 infection include fever, fatigue, cough, sore throat, breathing difficulty, myalgia, nausea, vomiting, and diarrhea, older people with medical comorbidities are more likely to get infected, with worse outcomes. Severe cases can lead to cardiac injury, respiratory failure, acute respiratory distress syndrome, and death (WHO,2020).

Based on existing epidemiological reports, the incubation time for Covid-19 infections varies from 1 to 14 days, usually from 3 to 7 days. Present statistics from childhood cases have shown that the disease age ranged from 1.5 months to 17 years, most of which had direct interaction with infected cases or were family cluster cases. Infected children can be asymptomatic or 
present with fever, dry cough, and weakness, and few have upper respiratory symptoms, including nasal congestion and runny nose; others have gastrointestinal symptoms, including stomach irritation, nausea, vomiting, abdominal pain, and diarrhea (WHO, 2019).

The Federal Government of Nigeria, in collaboration with the Federal Ministry of Health and the PTF-COVID-19, took a number of steps to halt the spread of the disease and protect Nigerians' health. This included a temporary suspension of non-essential activities, school closures, and a ban on international flights, among other things. Nigeria is one of the countries that began to ease the lockout measures put in place at the start of the COVID-19 pandemic. This is to strike a balance between saving life and livelihoods while still dealing with the outbreak's socioeconomic impact (Federal Ministry of health, 2020).

Studies have shown that the virus spreads from human-to-human mainly through respiratory droplets and body contacts. Contact with contaminated surfaces, hands, and touching of faceseye-nose-mouth are predominant ways to get exposed to the infected droplets. On top of this, some of the factors that aggravated the rapid spread of the virus were: first, on average, every case of COVID-19 will create up to 4 new cases (Cao, 2019).

The study analyzed the knowledge, attitude, perception of covid-19 prevention practices among residents in selected local government areas in Lagos State Nigeria.

To improve public health, it is very important to understand the role of infectious disease in our society by developing and practicing preventative efforts against infectious diseases. Involvement of peoples through health education prepares their minds on the need for regular and proper preventive measures such as regular hand washing, wearing of facemask and the use of hand sanitizer. Studies have shown that Hand washing with soap and clean water, use of hand sanitizer, not shaking hands and hugging and so on are always preferably more efficient in reducing the spread of covid-19. It is more effective to perform both hand hygiene and use antiseptic alcohol-based hand rubs. The use of alcohol hand sanitizers is mostly implemented when there is no soap and water. There are other instances that hinder the individual's ability to perform hand washing with soap and water. The use of alcohol hand-based disinfectants containing $60 \%$ alcohol is used in such cases. (CDC 2016). Understanding community members behavior and their relationship to their perceived risk is important in terms of health communication and effective control of an outbreak of infectious diseases, people can do a lot to keep themselves and others safe. 


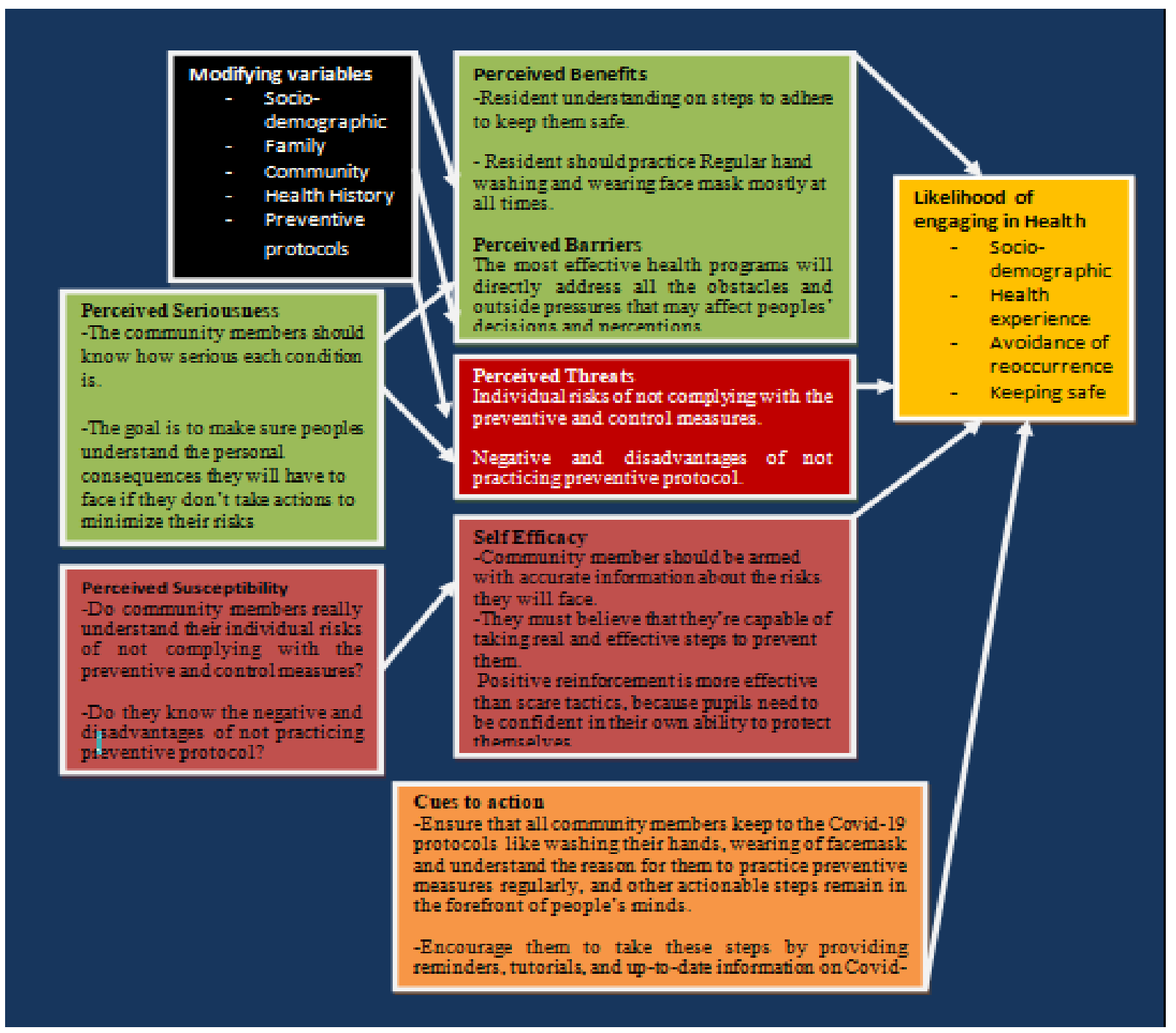

Fig 1: Health Belief Model

Nseobot \& Anietieimo's Covid-19 City Re-Entering Concept proposal, as represented in Nseobot\&Anietieimo's 2020 work, focuses mainly on how individuals, groups of citizens, corporate organizations, etc. will rebound from the unfriendly and harsh economic climate around the world to pursue their business operations. Their model principles of work clearly suggest a well-considered strategy that offers a linear or orderly way in which the phase of urban re-entry can benefit companies.

The creation of coronavirus is the result of the exploration, the quest for intelligence, either for gain or for firms that led to the coronavirus outbreak (Covid-19). This disease belongs to the pathogen family that triggers extreme acute respiratory syndrome (SARS) that can easily be contacted by another human. Various techniques and approaches are used to monitor the transmission of the infection, which has negatively influenced commercial practices across the globe. 
This control approach is used to minimise the possibility of transmitting the virus in culture. If the city needs to be reopened for entry and continued industrial, economic and social operations, there must be proof of improved control of the cases of covid-19 in the affected nations, there must be a downward trend in the curve of freshly reported cases and death. We may conclude, then, that there is greater regulation of the covid 19 cases. The re-opening of the city for activities is accompanied by a transition of activities and procedures, where company owners/managers must strive to keep on to their market shares, there has to be an appropriate mental re-orientation to adapt to the evolving circumstance. City re-entry approaches are a behavioural orientation and a trained plan for company owners/managers to enter the post-covid-19 culture.

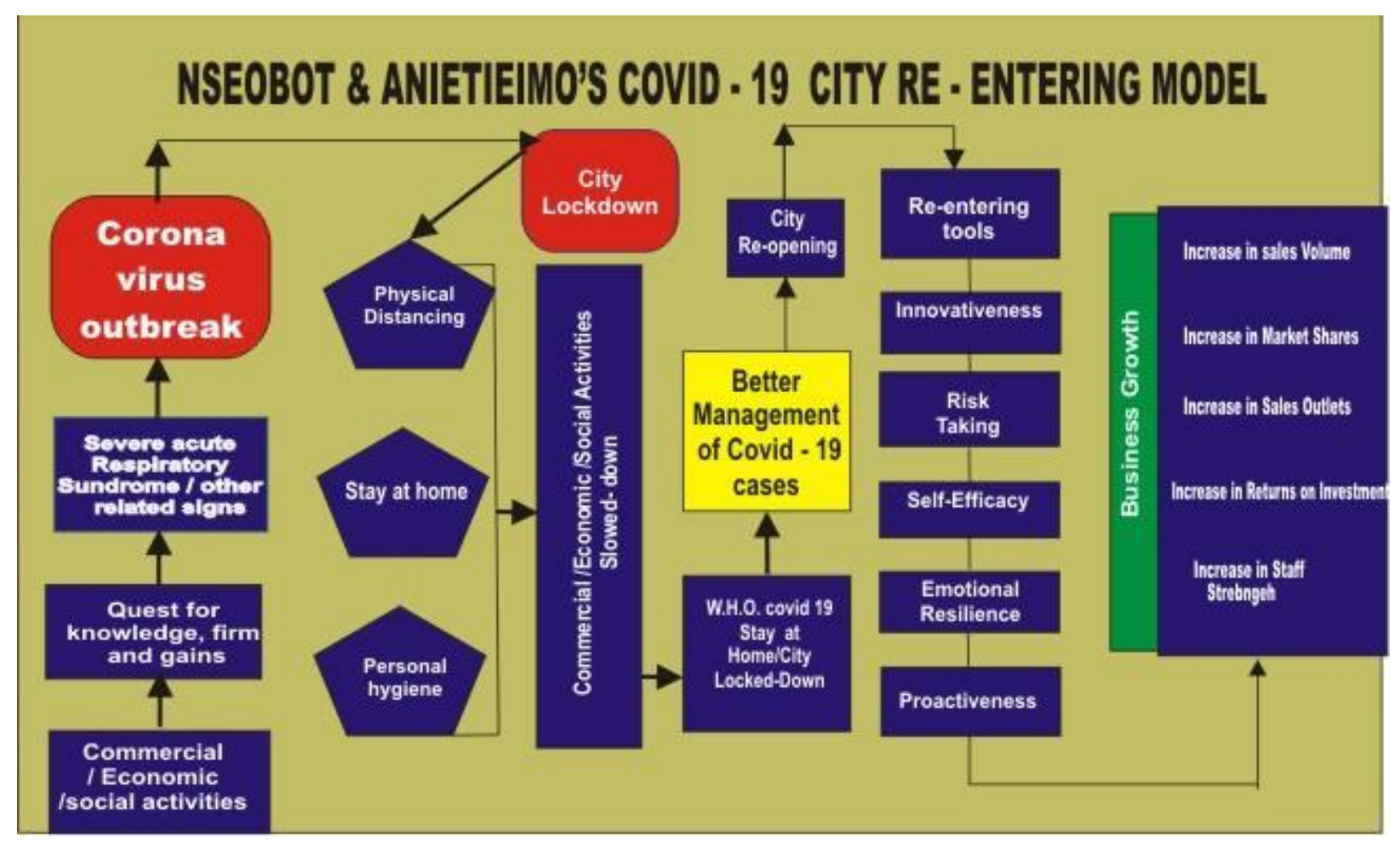

Fig. 2: Nseobot \& Anietieimo’s Covid-19 City Re-Entering Model (2020)

Most research on COVID-19 vaccines involves generating responses to all or part of the spike protein that is unique to the virus that causes COVID-19. When a person receives the vaccine, it will trigger an immune response. Vaccines can prevent infectious diseases. When most people in a community are protected by vaccination, the ability of the pathogen to spread is limited. This is called 'herd' or 'indirect' or 'population' immunity. When many people have immunity, this also indirectly protects people who cannot be vaccinated, such as those who have compromised immune systems (Who 2020).

Clinical trials are evaluating COVID-19 vaccines in tens of thousands of study participants to generate the scientific data and other information needed to determine safety and effectiveness, these clinical trials are being conducted by manufacturers according to rigorous standards. The 
COVID-19 vaccines are tested in a broad population of people -not only young, physically fit volunteers, but also older people and people with underlying health conditions, after deployment, the vaccines will continue to be carefully monitored for safety and effectiveness (Who 2020).

\section{MATERIALS AND METHODS}

\section{Study Area}

Lagos State is located in the south-western part of Nigeria on the narrow coastal flood plain of the Bight of Benin. It lies approximately between longitude 2o 42' E and 3o 22'E and between latitude 60 22'N and 6o 42' N. It is bounded in the North and East by Ogun State of Nigeria, in the West by the Republic of Benin, and in the South by the Atlantic Ocean. It has five administrative divisions of Ikeja, Badagry, Ikorodu, Lagos Island and Epe which were subdivided to 20 Local Government Areas (LGAs) during the creation of States and LGAs in Nigeria in 1999. Presently, there has been a creation by the State Government of 37 Local Council Development Areas (LCDA) in addition to the 20 LGAs making a total of 57 Local government administrative units. Territorially, Lagos State encompasses an area of 358,862 hectares or 3,577 sq. km which is about 0.4 percent of the total land area of Nigeria, The dominant vegetation of the State is the tropical swamp forest consisting of fresh water and mangrove swamp forests both of which are influenced by the double rainfall pattern of the State, which makes the environment a wetland region, hence, the reference to Lagos as an environment of aquatic splendor.

The population of Lagos State by the 2006 National Census conducted by the National Population Commission was 17,552,942. The initial discrepancy between the Federal and State Governments has been harmonized through appropriate legal adjudication. Going by a population growth rate of 3.2 percent, the projected population for the State in 2015 is 23,305,971 (Bureau of Statistics, 2013). Lagos megacity contains urban, semi-urban and rural communities, though rapid expansion and development is changing the distribution rapidly. Urban areas are those with a population greater than 20,000, semi-urban areas are those with a population of between 5000 and 20,000 while rural areas are those communities with a population of less than 5000 .

\section{Study Design/Population}

The population of this study consists of all the residents in the selected local government area of Lagos State.

\section{Sampling Size}

The population of the study are three (3) selected local Government areas, four hundred and twenty (420) residents will be randomly selected using Leslie Fisher's formula for sample size determination. $10 \%$ attrition added to calculated sample size

$\mathrm{n}=\mathrm{Z}^{2} \mathrm{Pq} / \mathrm{e}^{2}$

$\mathrm{e}=$ level of precision at 0.05 
African Journal of Biology and Medical Research

ISSN: 2689-534X

Volume 4, Issue 3, 2021 (pp. 17-38)

$\mathrm{Z}=1.96$

$\mathrm{Q}=1-\mathrm{p}$ where $\mathrm{p}$ is rated at a level of $42 \%$ which is 0.42

$\mathrm{n}=$ Sample size expected

$\mathrm{n}=1.96^{2 * 0.42(1-0.42) / 0.05^{2}}$

$\mathrm{n}=3.8416 * 0.42 * 0.58 / 0.0025$

$\mathrm{n}=0.9358 / 0.0025$

$\mathrm{n}=374.32$

$\mathrm{n}=374$

$\mathrm{n}=374+38$

$n=412$

\begin{tabular}{|l|l|}
\hline Selected LGA's & Sample size \\
\hline Ikeja, & 140 \\
\hline Mushin & 140 \\
\hline Surulere & 140 \\
\hline Total & 420 \\
\hline
\end{tabular}

\section{Data Collection Instrument}

Appropriate authority of the community was informed and appointments were made with local government authority. The residents were approached during their daily activities in their houses, offices, shops, marketplaces and place of worship. Residents were informed on the purpose of the study. All residents who are consented and have accepted to partake in the survey were asked to complete the questionnaire. The questionnaires were administered with the help of three research assistants from each Local Government Area who were adequately briefed on the purpose and modalities of the instrument appropriately. Therefore, the research assistants volunteered to monitor and collect the completed questionnaire. All completed questionnaires were collected for analysis.

\section{Inclusion criteria}

- $\quad$ Registered residence in selected LGA's who accept to participate in the study.

\section{Exclusion criteria}

- Residents who are younger than 10 years will be excluded from this study.

- Also, residence who do not give consent for this study will be excluded 
African Journal of Biology and Medical Research

ISSN: 2689-534X

Volume 4, Issue 3, 2021 (pp. 17-38)

www.abjournals.org

\section{Sampling Technique}

A multistage sampling procedure was used for selection of respondents in the study areas.

Stage 1: Random selection of three out of the twenty-one local government of Lagos State, Nigeria.

Stage 2: Selection of communities in the selected local government in the study areas.

Stage 3: Random selection of $10 \%$ of respondents from the chosen communities.

\section{Ethical Consideration}

Ethical consent was acquired from Babcock University Research Ethics Committee. Permission was also obtained from the study area residence, local authority and security. Respondents were educated on the motive of this study so as to enable them to participate effectively. Privacy and secrecy was guaranteed during the course of the study as private information was not disclosed by respondents in the questionnaire.

\section{RESULTS}

Four hundred and twenty questionnaires (420) were administered, and four hundred were completely and correctly filled. The response rate was $95.2 \%$.

The mean age of the respondents was $38.43 \pm 16.4$ years. The ages of the majority $118(29.5 \%)$ of the respondents, fell within the 30 to 39 years age range. Most 251(62.8\%) of the respondents were female while less than half $158(39.5 \%)$ of the respondents were Muslims. More than half $208(52.0 \%)$ of the respondents were married. Few 135(33.8\%) of the respondents had tertiary education, with less than half $151(37.8 \%)$ of the respondents without formal education. Most $174(43.4 \%)$ of the respondents are Artisans.

Less than half $167(41.8 \%$ ) of the respondents earned between $\$ 50,000$ and $\$ 100,000$ monthly. (See, Table 4.1)

Respondents' knowledge of COVID 19 measured on a 21-point rating scale showed a mean score of $13.86 \pm 2.73$. Respondents' knowledge was then categorized into three, poor (0-7.9), fair (8.0-14.9) good (15.0-21). More than half 241(60.3\%) of the respondents had fair knowledge about COVID19, with $159(39.8 \%)$ of the respondents having good knowledge. (See, Table 4.2.1)

Respondent's perception of COVID 19 prevention measured on a 27-point rating scale showed a mean score of 12.21 \pm 2.09 . Respondents' perception was then categorized into two, low perception (0-13.5) and high perception (13.6-27). Most 279(69.8\%) of the respondents had low perception of COVID19 prevention while 121(30.2\%) of the respondents had high perception (See, Table 4.3.1).

Respondent's attitudinal disposition towards COVID19, prevention measured on a 36-point rating scale showed a mean score of 11.92 \pm 1.39 . Respondent's attitudinal disposition was then categorized into two; negative attitude (0-18.9) and positive attitude (19.0-36). All 400(100\%) 
African Journal of Biology and Medical Research

ISSN: 2689-534X

Volume 4, Issue 3, 2021 (pp. 17-38)

www.abjournals.org

the respondents had negative attitudinal disposition towards COVID19 prevention, (See, Table 4.4.1)

Respondents' prevention practices were then categorized into two; poor (0-9.9) and good (10.018). Slightly half $262(67.8 \%)$ of the respondents had poor prevention practices, while, $198(49.5 \%)$ of the respondents had good prevention practices (See, Table 4.5.1).

Table 4.1 Socio-demographic Characteristics of the Respondents

\begin{tabular}{|c|c|c|}
\hline \multirow[t]{2}{*}{ Socio-demographic variables for consideration } & \multicolumn{2}{|c|}{ Respondents in this study; $\mathrm{N}=400$} \\
\hline & Frequency $(\mathbf{n})$ & Percentage $(\%)$ \\
\hline \multicolumn{3}{|l|}{ Age (in years) } \\
\hline \multicolumn{3}{|l|}{ Age (in years) $\overline{\mathbf{x}} 38.42 \pm \mathbf{1 6 . 4 1}$} \\
\hline $10-19$ & 23 & 5.8 \\
\hline $20-29$ & 106 & 26.5 \\
\hline 30-39 & 118 & 29.5 \\
\hline $40-49$ & 71 & 17.7 \\
\hline $60-69$ & 23 & 5.8 \\
\hline 70-79 & 12 & 3.0 \\
\hline 80-89 & 8 & 2.0 \\
\hline 50-59 & 30 & 7.5 \\
\hline $90-99$ & 6 & 1.5 \\
\hline 100-109 & 3 & 0.7 \\
\hline \multicolumn{3}{|l|}{ Religion } \\
\hline Christian & 131 & 32.8 \\
\hline Muslim & 158 & 39.5 \\
\hline Traditional & 111 & 27.7 \\
\hline \multicolumn{3}{|l|}{ Education } \\
\hline No formal education & 151 & 37.7 \\
\hline Primary & 25 & 6.3 \\
\hline Secondary & 89 & 22.3 \\
\hline Tertiary & 135 & 33.7 \\
\hline \multicolumn{3}{|l|}{ Marital Status } \\
\hline Single & 97 & 24.2 \\
\hline Married & 208 & 52.0 \\
\hline Divorce & 53 & 13.3 \\
\hline Widow & 42 & 10.5 \\
\hline \multicolumn{3}{|l|}{ Occupation } \\
\hline Civil servant & 69 & 17.3 \\
\hline Traders & 157 & 39.3 \\
\hline Artisans & 174 & 43.4 \\
\hline \multicolumn{3}{|l|}{ Sex } \\
\hline Female & 251 & 62.8 \\
\hline Male & 149 & 37.2 \\
\hline \multicolumn{3}{|l|}{ Monthly income } \\
\hline Less than 50,000 & 96 & 24.0 \\
\hline Between 50,000 -100,000 & 167 & 41.8 \\
\hline More than 100,000 & 137 & 34.2 \\
\hline
\end{tabular}


Table 4.2 Knowledge of the Respondents' Regarding COVID19

Variable

Have you heard of COVID 19

COVID-19 19 spread from person to person within close distance of each other

COVID-19 19 spread through respiratory droplets, which occur when infected people couch and sneeze COVID 19 can be contracted by touching a surface or object, on which the virus is attached, and then touching one's mouth, nose, or perhaps eyes.

Close contact or eating wild animals causes COVID19 People infected with COVID 19 can transmit the virus to others even when a fever is not present.

The main clinical symptoms of COVID 19 are fever, fatigue, dry cough and shortness of breath.

Unlike the common cold, congestion, runny nose, and sneezing are less common in the people infected with COVID 19

Antibiotics are an effective treatment for COVID 19

There is no effective cure for COVID 19, but early symptomatic and supportive treatment can help most patients recover from the disease.

Older adults and those with serious chronic illnesses such as heart or lung disease and diabetes are at increased risk of developing more serious complication from COVID 19

Not all people with COVID 19 have severe cases. Only older adults with chronic illness.

Pregnant women are more susceptible to infections than non-pregnant women

\begin{tabular}{ll}
\multicolumn{3}{c}{$\begin{array}{r}\text { Respondents in this } \\
\text { study }=400\end{array}$} \\
Frequency $(\mathrm{n})$ & Percent $(\%)$ \\
400 & 100 \\
387 & 96.8
\end{tabular}


Table 4.2.1 Knowledge of the Respondents' Regarding COVID19

Variable

Children do not appear to be at higher risk for COVID 19 than adult it is not necessary for children or young people to take precautionary measures to prevent COVID19 transmission

After being in a public place. After nose-blowing, coughing or sneezing, people must wash their hands with soap and water or use hand sanitizer containing at least $60 \%$ alcohol, for at least 20 seconds

Ordinary residents can wear general medical mask to 242 prevent COVID 19 infection

People should only wear a mask if they are infected with the virus, or they are caring for someone with suspected COVID 19 infection.

Healthy food and drinking water increase the body's 260 immunity and resistance to COVID19

Isolation and treatment of people infected with COVID!9, 245 are effective ways to reduce the spread of virus

People in contact with someone infected with COVID 19250 should be immediately quarantined, in an appropriate location, for a general observation period of 14 days To prevent transmission of COVID19, people must avoid going to crowded places and avoid taking public transport.

\author{
Respondents in this \\ study $=400$ \\ Frequency(n) Percent (\%) \\ $203 \quad 50.8$
}

274

68.5

60.5

46.8

52.5

Table 4.2.2 Respondents Level of Knowledge Regarding COVID19

\begin{tabular}{lll}
\hline & Respondents in this study; $\mathbf{N}=\mathbf{4 0 0} \overline{\mathbf{x}} \overline{\mathbf{x}}=\mathbf{1 3 . 8 6} \pm \mathbf{2 . 7 3}$ \\
& Frequency & Percentage $(\%)$ \\
Poor (0-7.9) & 0 & 0.0 \\
Fair $(\mathbf{8 . 0 - 1 4 . 9 )}$ & 241 & 60.3 \\
Good (15.0-21) & 159 & 39.8 \\
\hline
\end{tabular}




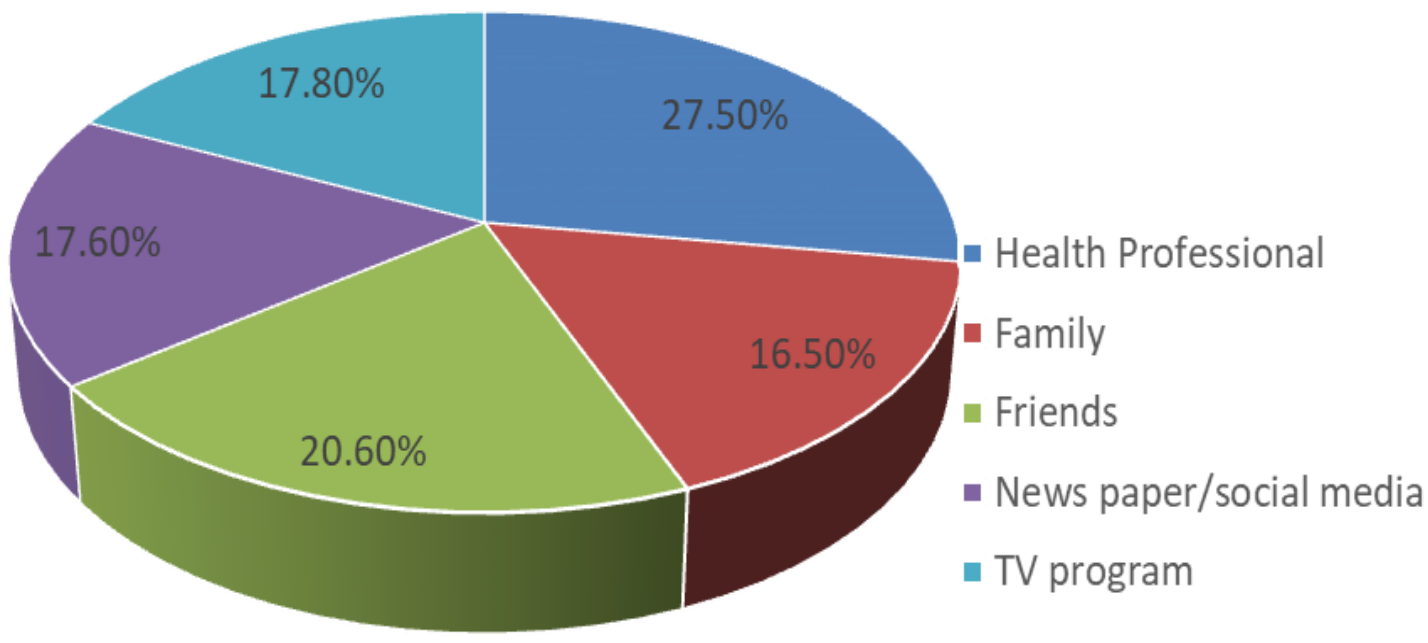

Figure 4.2 Respondents' Sources of Information for COVID19

Table 4.3. Respondents Perception of COVID19 prevention

\begin{tabular}{|c|c|c|c|c|}
\hline Statements & $\begin{array}{c}\text { Strongly } \\
\text { Agree } \\
\text { F (\%) }\end{array}$ & $\begin{array}{l}\text { Agree } \\
\mathrm{F}(\%)\end{array}$ & $\begin{array}{c}\text { Disagree } \\
\text { F }(\%)\end{array}$ & $\begin{array}{c}\text { Strongly } \\
\text { disagree } \\
\text { F (\%) }\end{array}$ \\
\hline I fear COVID 19 & $* 262(65.5)$ & $63(15.8)$ & $43(10.8)$ & $32(8.0)$ \\
\hline $\begin{array}{l}\text { I am scared because my family } \\
\text { have older adults }\end{array}$ & $* 74(18.5)$ & $213(53.3)$ & $64(16.0)$ & $49(12.3)$ \\
\hline $\begin{array}{l}\text { Aggressive screening would help } \\
\text { the management of COVID } 19\end{array}$ & $* 125(31.3)$ & $178(44.5)$ & $74(18.5)$ & $23(5.8)$ \\
\hline $\begin{array}{l}\text { COVID } 19 \text { is can be treated at } \\
\text { home }\end{array}$ & $113(28.3)$ & $193(48.3)$ & $66(16.5)$ & $28(7.0)^{*}$ \\
\hline COVID 19 is a serious disease & $* 135(33.8)$ & 194(48.5) & $58(14.5)$ & $13(3.3)$ \\
\hline $\begin{array}{l}\text { Early detection of COVID } 19 \text { can } \\
\text { improve treatment and outcome }\end{array}$ & $* 154(38.5)$ & $188(47.0)$ & $44(11.0)$ & $14(3.5)$ \\
\hline COVID 19 is a curable disease & $* 140(35.0)$ & $202(50.5)$ & $39(39.0)$ & $19(4.8)$ \\
\hline $\begin{array}{l}\text { COVID } 19 \text { disease results in death } \\
\text { in all cases }\end{array}$ & $93(23.3)$ & $153(38.3)$ & $88(22.0)$ & $66(16.5)^{*}$ \\
\hline $\begin{array}{l}\text { COVID } 19 \text { can be avoided by } \\
\text { taking the precautionary measures }\end{array}$ & $* 138(34.8)$ & $168(42.0)$ & $\begin{array}{l}68(17.0 \\
\%)\end{array}$ & $25(6.3)$ \\
\hline
\end{tabular}

*Expected Response 
Respondents' Perception of COVID19 Prevention

\begin{tabular}{lll}
\hline & Respondents in this study; $\mathrm{N}=400 \overline{\mathrm{x}}=12.21 \pm 2.09$ \\
& Frequency & Percentage $(\%)$ \\
Low (0-13.5) & 279 & 69.8 \\
High (13.6-27) & 121 & 30.3 \\
\hline
\end{tabular}

Table 4.4 Respondents Attitudinal Disposition towards COVID19 Prevention

\begin{tabular}{|c|c|c|c|c|}
\hline \multirow[t]{3}{*}{ Statement } & \multirow[t]{2}{*}{$\begin{array}{l}\text { Strongly } \\
\text { Agree }\end{array}$} & Agree & Disagree & \multirow[t]{2}{*}{$\begin{array}{l}\text { Strongly } \\
\text { Disagree }\end{array}$} \\
\hline & & $\mathrm{F}(\%)$ & $\mathrm{F}(\%)$ & \\
\hline & $\mathrm{F}(\%)$ & & & $\mathrm{F}(\%)$ \\
\hline $\begin{array}{l}\text { It is important to keep my distance from } \\
\text { others, to avoid spreading COVID } 19\end{array}$ & $* 313(78.3)$ & $80(20.0)$ & $5.0(1.3)$ & $2.0(0.5)$ \\
\hline $\begin{array}{l}\text { Washing hands is essential to protect } \\
\text { myself from COVID } 19\end{array}$ & $* 119(29.8)$ & $270(67.5)$ & $112(0.8)$ & $00(00)$ \\
\hline $\begin{array}{l}\text { To protect myself from COVID } 19 \\
\text { exposure, I should stay home if I am } \\
\text { sick, unless I am receiving medical care }\end{array}$ & $* 156(39.0)$ & $173(43.3)$ & $64(16.0)$ & $7.0(1.8)$ \\
\hline $\begin{array}{l}\text { COVID-19 will eventually be } \\
\text { successfully controlled }\end{array}$ & $* 207(51.8)$ & $145(36.3)$ & $41(10.3)$ & $7(1.8)$ \\
\hline $\begin{array}{l}\text { Strict measures can help win the battle } \\
\text { against COVID19 }\end{array}$ & $* 179(44.8)$ & $196(49.0)$ & $18(4.5)$ & $7(1.8)$ \\
\hline $\begin{array}{l}\text { Compliance with NDCD precautions will } \\
\text { prevent spread of COVID } 19 .\end{array}$ & $* 190(47.5)$ & $186(46.5)$ & $24(6.0)$ & $0(0.0)$ \\
\hline $\begin{array}{l}\text { The awareness considering COVID } 19 \\
\text { disease in society is sufficient }\end{array}$ & $* 128(32.0)$ & $214(53.5)$ & $51(12.8)$ & $7(1.8)$ \\
\hline COVID-19 is like common flu & $* 120(30.0)$ & $176(44.0)$ & $81(20.3)$ & $23(5.8)$ \\
\hline COVID-19 is a religious curse & $125(31.3)$ & $164(41.0)$ & $51(12.8)$ & $\begin{array}{l}* 60 \\
(15.0)\end{array}$ \\
\hline $\begin{array}{l}\text { Media coverage about this disease is } \\
\text { exaggerated }\end{array}$ & $140(35.0)$ & $173(43.3)$ & $56(14.0)$ & $* 31(7.8)$ \\
\hline $\begin{array}{l}\text { Hand sanitizers, hand soap and mask } \\
\text { should be provided freely }\end{array}$ & $* 152(38.0)$ & $154(38.5)$ & $57(14.3)$ & $37(9.3)$ \\
\hline $\begin{array}{l}\text { Government should restrict travel to } \\
\text { and from COVID } 19 \text { disease areas to } \\
\text { prevent contamination }\end{array}$ & $* 134(33.5)$ & $144(36.0)$ & $75(18.8)$ & $47(11.8)$ \\
\hline
\end{tabular}

*Expected responses 
Category of Respondents Attitudinal Disposition towards COVID-19 Prevention

\begin{tabular}{lll}
\hline & Respondents in this study; $\mathrm{N}=400 \overline{\mathrm{x}} \overline{\mathrm{x}}=11.92 \pm 1.39$ \\
& Frequency & Percentage $(\%)$ \\
Negative (0-18.9) & 400 & 100 \\
Positive(19.0-36) & 0 & 0.0 \\
\hline
\end{tabular}

Table 4.5. Respondents' Prevention Practices of COVID19

Variable

Do you participate in meetings, religious activities, events and other social gatherings in your areas with ongoing community transmission?

In recent days, have you worn a mask when leaving home?

If yes, do you touch the front of the mask when taking it off?

Do you reuse a mask?

Do you wash your hands with soap and water frequently for at least 20seconds or use hand sanitizer

Do you touch your eyes, nose, and mouth frequently with unwashed hands?

Do you clean and disinfect frequently touched objects and surfaces

Do you practice ' physical distancing' by remaining 6 feet/2meters away from others

Do you use other worker' phones, desks, office or other work tools and equipment

Do you limit contact (such as handshakes)

Do you eat or drink in bars and restaurants?

Do you cover your nose and mouth during coughing or sneezing with elbow or a tissue paper and trash

Do you prefer to stay at home, in a room with open during the transmission period

Do you stay home when you were sick due to common cold-like infection during the transmission period
Respondents in this study $=400$

Frequency(n) Percent $(\%)$

235

58.8

227

56.8

157

69.2

48.0

316

79.0

206

51.5

295

222

290

72.5

201

50.3

265

66.3

242

60.5

295

73.8

234 
In order to prevent contracting COVID 19, I use herbal

products and traditional medicine

I take vitamin Supplement in order to prevent

contracting COVID 19

\begin{tabular}{lll}
\hline & Respondents in this study; $\mathbf{N}=\mathbf{4 0 0} \overline{\bar{\square}} \mathbf{\overline { \square }}=\mathbf{9 . 3 5} \pm \mathbf{2 . 9 0}$ \\
& Frequency & Percentage $(\boldsymbol{\%})$ \\
Low $(0-9.9)$ & 262 & 50.5 \\
High $(10.0-18)$ & 198 & 49.5 \\
\hline
\end{tabular}

\section{Test of hypotheses}

Three hypotheses were tested for this study. In testing these hypotheses, Pearson correlation and linear regression was conducted at 0.05 level of significance. The decision rule applied was that if the $p$-value computed was less or equal to the cut-off $p$-value of 0.05 , the null hypothesis will be rejected in favor of the alternative hypothesis and vice-versa.

Hypothesis 1: there is no significant relationship between respondent's level of knowledge and their preventive practices of COVID19.

The result of the correlation analysis showed that there is a significant relationship between respondent's level of knowledge and their prevention practices of COVID19 ( $\mathrm{r}=0.14, \mathrm{p}$ value $=0.00)($ Table 4.8).

Also, the linear regression analysis showed that respondents' knowledge contributed $19 \%$ to the respondent's prevention practices $\left(\mathrm{R}=0.44 ; \mathrm{R}^{2}=0.19 ; \mathrm{p}=0.00\right)$ (See, Table4.8.1).

Therefore, based on these values, respondent's level of knowledge about COVID 19 and their preventive practices had a relationship. Hence the null hypothesis is rejected.

Hypothesis 2: there is no significant relationship between respondent's perception and their preventive practices of COVID19. The result of the correlation analysis showed that there is a significant relationship between respondent's perception and their prevention practices of COVID19 $(\mathrm{r}=0.10, \mathrm{p}$ value $=0.04)$ (Table 4.8). Also, the linear regression analysis showed that 
respondents' perception contributed $30 \%$ to the respondent's prevention practices $(R=0.10$; $\left.\mathrm{R}^{2}=0.30 ; \mathrm{p}=0.00\right)($ See, Table4.8.1).

Therefore, based on these values, the respondent's attitude about COVID 19 and their preventive practices had a relationship. Hence the null hypothesis is rejected.

Hypothesis 3: there is no significant relationship between respondent's attitude and their preventive practices of COVID19. The result of the correlation analysis showed that there is a significant relationship between respondent's attitudinal disposition and their prevention practices of COVID19 $(\mathrm{r}=0.27$, $\mathrm{p}$ value $=0.00)($ Table 4.8).

Also, the linear regression analysis showed that respondents' attitudinal disposition contributed $29 \%$ to the respondents prevention practices $\left(\mathrm{R}=0.27 ; \mathrm{R}^{2}=0.29 ; \mathrm{p}=0.00\right)$ (See, Table4.8.1). Therefore, based on these values, respondent's attitudinal disposition about COVID 19 and their preventive practices had a relationship. Hence the null hypothesis is rejected.

Table 4.8 Relationship between Respondents Knowledge, Perception, Attitude, and Prevention practices of COVID19

\begin{tabular}{llc}
\hline Variable & \multicolumn{2}{c}{ Prevention Practices of COVID19N=400 } \\
& $\mathrm{r}$ & $\mathrm{p}-\mathrm{value}$ \\
Knowledge & 0.44 & 0.00 \\
Perception & 0.10 & 0.04 \\
Attitude & 0.27 & 0.00
\end{tabular}

Table 4.8.1 Association between Respondents, Knowledge, Perception,Attitude, and prevention practices on COVID19

\begin{tabular}{lllllll}
\hline & \multicolumn{7}{l}{ Prevention Practices of COVID19 N=400 } & \\
\cline { 2 - 7 } & $\mathrm{R}$ & R square & $\mathrm{B}$ & Beta & $\mathrm{F}$ & p-value \\
Knowledge & 0.44 & 0.19 & 0.47 & 0.445 & 98.39 & 0.000 \\
Attitude & 0.54 & 0.29 & 0.63 & 0.29 & 51.95 & 0.00 \\
Perception & 0.54 & 0.30 & 0.14 & 0.10 & 5.60 & 0.04 \\
Adherence & 0.24 & 0.60 & 0.43 & 0.24 & 25.19 & 0.00 \\
\hline
\end{tabular}

\section{DISCUSSION}

From the study carried out on the knowledge, attitude and perception of COVID-19 prevention practices, it was reported that knowledge was satisfactory among the respondents. For instance, more than $(60 \%)$ of the respondents knew about COVID-19. This could be because of the moderately high level of secondary and tertiary education that the respondents had and the level of awareness that was generated. The respondents confirmed that they got their source from 
health professionals, friends, news/social media and TV programs respectively. This was in agreement with previous findings done in different countries, Zhong,et al., (2020), Winter, et al., (2020), Azlan et al.,(2020). Egypt, Abdelhafiz et al., (2020) Kenya, Pinchoff et al., (2020) and Nigeria, Olapegba et al., (2020). The current results showed that most of the participants depended more on the health professional and social media/friends to get their information about the COVID-19, In contrast to other studies among Jordanian, Egyptian and Pakistani populations that were using mostly social media as the main source of information Abdelhafez, et al. (2020). The differences may be due to different study locations.

The study revealed that the respondents had fair knowledge of COVID-19 prevention. This finding is at variance with the findings Olapegba et al., (2020), Austrian et al., (2020) and Abdelhafz, et al. (2020) where they indicated high COVID-19 knowledge among the population.

Nevertheless, the results from our study showed that the fair knowledge exhibited by our respondents translated into good and safe practices as the majority of the participants were involved in maintaining hand hygiene at all times, avoiding the touching of the eyes and mouth with unwashed hands and washing of hands with soap and water after removing them regularly. This is a reflection of the increasing concern of our study participants towards personal hygienic measures geared towards avoiding COVID-19 infection. Concerning the preventive practices, it was observed that less than half of the respondents had appropriate preventive behaviors. But the result was at variance with the study conducted in Ethiopia, Adhena, Hidru (2020), Cameroon Nicholas, Vanessa, et al. (2020), and in the Democratic republic of Congo Musa, Obadia, et al (2020) where it was reported that there was a high prevention of COVID19.The findings of the study revealed that $(61.3 \%)$ of the respondents thought that people with infection cannot transmit the disease to others when a fever is not present. This poor knowledge could be because of inadequate information they received regarding COVID-19. The study showed that the respondents had poor attitudinal disposition towards COVID-19 prevention.

The study found that slightly half of the respondents had poor prevention practices. This result is at variance with the report ofAzlan, et al., (2020) in Malaysia but similar to the result of Zhong et al (2020) in China. All the respondents had negative attitudes towards COVID-19 prevention; this finding is in contrast to a study conducted in Saudi where the majority of the respondents reported a positive and optimistic attitude towards COVID-19, (Mohammedet al,2020). Only $29.8 \%$ of the respondents strongly agreed that washing hands is essential to protecting oneself from contracting COVID-19. This attitude was in sharp contrast to the study done in Egypt and some parts of Nigeria, where all of the respondents agreed on the importance of hand washing and other preventive measures in reducing the chances of being infected. A positive attitude towards most preventive measures were earlier reported in India by Roy, Tripathi Karan,Sharma,Verma, Kaushal (2020).

The result of the study also showed most of the respondents had low perception of COVID-19 prevention. This finding is at variance with the report of Alrubaiee, (2020) where majority of the respondents had high perception of COVID-19 (Alrubaiee, 2020).

The result showed that there was a significant relationship between knowledge of respondents, perception, attitude and their prevention practices to COVID-19. This was in congruence to a study carried out by (Roy et al., 2020). This implies that promoting preventive behaviors toward COVID-19 would require promoting knowledge, perception and attitude among the 
public. This is similar to the finding of Lee \& You (2020). This study also displayed that for the public to perform precautionary behaviors after acquiring information, they then need to perceive that such practices would be effective. For example, people need to believe that washing hands would keep them from being infected, beyond merely being informed so, to perform and sustain their behavior.

\section{SUMMARY}

Three research hypotheses were formulated and tested at 0.05 alpha level. The study adopted a cross-sectional design. Multi-stage sampling technique was used to select three LGAs, Mushin, Ikeja, Surulere. Four hundred respondents were selected. A validated questionnaire which was self-administered was used for data collection. Data collected were analyzed by using descriptive statistics of frequency tables, chart, mean, standard deviation and inferential statistics of, correlation, and multiple regressions. The results revealed that the majority of the respondents had fair knowledge, moderate perception, negative attitudinal and moderate adherence to COVID-19 prevention. There is a significant relationship between respondents, knowledge, perception, attitude and their prevention of COVID-19. Also, there is a relationship between respondents' socio-demographic characteristics such as age, religion, occupation, education and prevention practices.

\section{CONCLUSION}

In conclusion, the current study provided a comprehensive look at the knowledge, attitude and perception of COVID19 prevention practices among residents of selected local government areas in Lagos Nigeria. The participants had a high level of knowledge about the virus and good practice towards using protective measures, which is significant towards controlling the spread of the virus. But the attitudinal disposition of the respondent's was negative; this could be because of inadequate information regarding the virus. This study recommends developing informative COVID-19 related campaigns, and providing necessary protective mask and hand sanitizers for the residence of this community.

\section{RECOMMENDATION}

Based on the findings of this study the following are therefore recommended;

1. Effective health education campaigns aimed at enhancing the attitude of COVID-19 are therefore desperately needed to promote a positive mindset and maintain appropriate preventive practices.

2. Health campaigns should be more focused on practices such as regular hand-washing with soap and water and social distancing, which protect against transmission of COVID19 among community members irrespective of their sex. 
African Journal of Biology and Medical Research

ISSN: 2689-534X

Volume 4, Issue 3, 2021 (pp. 17-38)

www.abjournals.org

\section{Funding Source}

Woorergold Cloud - Skin Healthcare Therapeutic Center

\section{Residents Consent}

Consent was obtained from residents regarding this study.

\section{Conflict Of Interest}

No conflict of interest to declare by any of the author

\section{REFERENCES}

[1] Abdelhafiz, A., Mohammed, Z., Ibrahim, M., Ziady, H., Alorab, M., Ayyad, M., \& Sultan, E. (2020). Knowledge, perceptions, and attitude of Egyptians towards the novel coronavirus disease (COVID-19) Journal of Community Health.

[2] Abdelhafiz, A., Mohammed, Z., Ibrahim, M., Ziady, H., Alorab, M., Ayyad, M., \& Sultan E. (2020). Knowledge, perceptions, and attitude of Egyptians towards the novel coronavirus disease (COVID-19) Journal of Community Health.

[3] Abdelhafz, A., Mohammed, Z., Ibrahim, M., Ziady, H., Alorabi, M.,\&Ayyad M. (2020). Knowledge, Perceptions, and Attitude of Egyptians Towards the Novel Coronavirus Disease (COVID-19). Journal of Community Health, 45:881-890 pmid:32318986

[4] Adhena, G., \&Hidru, H.(2020). Knowledge, Attitude, and Practice of High-Risk Age Groups to Coronavirus Disease-19 Prevention and Control in Korem District, Tigray, Ethiopia: Cross-Sectional Study. Infection and Drug Resistance, 13:3801.

[5] Alrubaiee, G., Al-Qalah, T., \& Al-AawarA. (2020). Knowledge, attitudes, anxiety, and preventive behaviours towards COVID-19 among health care providers in Yemen: an online cross-sectional survey. BMC Public Health.

[6] Anikwe, C., Ogah, C., Anikwe, I., Okorochukwu, B.,\&Ikeoha C.(2020). Coronavirus disease 2019: Knowledge, attitude, and practice of pregnant women in a tertiary hospital in Abakaliki, southeast Nigeria. International Journal Gynecology Obstetric, 151(2):197-202.

[7] Austrian ,K., Pinchoff, J., Tidwell, J., White, C., Abuya, T., \& Kangwana, B (2020). COVID-19 related knowledge, attitudes, practices and needs of households in informal settlements in Nairobi, Kenya. Bulletin of the World Health Organization.

[8] Austrian, K., Pinchoff, J., Tidwell, J., White, C., Abuya, T., \&Kangwana, B. (2020). COVID-19 related knowledge, attitudes, practices and needs of households in informal settlements in Nairobi, Kenya. Bulletin of the World Health Organization.

[9] Azlan, A., Hamzah, M., Sern, T., Ayub, S., \&Mohamad, E. (2020). Public knowledge, attitudes and practices towards COVID-19: A cross-sectionalstudy in Malaysia. PLoS ONE,15(5): 0233668 .

[10] Cao JL, Tu WJ, Hu XR, \& Liu Q. (2020).Clinical Features and Short-term Outcomes of 102 Patients with CoronaVirus Disease 2019 in Wuhan, China.Clinical Infectious Diseases. PMID: 32239127

[11] Cao Z. Estimating the elective reproduction number of 2019-nCoV in China.medRxiv 2020. [CrossRef]. 
African Journal of Biology and Medical Research

ISSN: 2689-534X

Volume 4, Issue 3, 2021 (pp. 17-38)

www.abjournals.org

[12] Carsi, KT., Kamanda M.C., Pyana,K.J., Kazadi, N.,Muta, M., \& Musa O.(2020). COVID-19 Pandemic: Knowledge and Attitudes in Public Markets in the Former Katanga Province of the Democratic Republic of Congo. Int J Environ Res Public Health. 2020

[13] Center for Strategic Studies. Jordanian Index Surveys Series: Jordanian Street Pulse 24 Amman: University of Jordan; 2020 [updated October 6; cited 2020 December 20]. Available from: http://jcss.org/ShowNewsAr.aspx?NewsId=862.

[14] Coronavirus Update (Live).https:// www.worldometers.info > coronavirus

[15] Coustasse A, Kimble C, Maxik K. COVID-19 and Vaccine Hesitancy: A Challenge the United States Must Overcome. J Ambul Care Manage. 2021;44(1).

[16] Cvetkovic', V.; Ristanovic', E.; Gac 'ic', J. Citizens attitudes about the emergency situations caused by epidemics in serbia. Iran. J. Public Health 2018, 47, 1213-1214. 14.

[17] Cvetkovic',V.Percepcijajavnostiopripremljenostizabiosferskekatastrofeizazvaneepidemi jama-ImPlikacije naprocesupravljanjarizicima [Public perceptions of epidemic preparedness for biosphere catastrophes-Implications for the risk management process]. Bezbednost 2018, 60, 5-25. [CrossRef]

[18] Fine P, Eames K, Heymann DL. "Herd Immunity": A Rough Guide. Clin Infect Dis. 2011;52(7):911-6. doi: 10.1093/cid/cir007.

[19] Holshue M.L. First Case of 2019 Novel Coronavirus in the United States. N. Engl. J. Med. 2020. [CrossRef] [PubMed].

[20] Jordan to Begin Covid-19 Vaccination Drive by February - Health Minister Amman: Jordan Times; 2020 [cited 202015 December].

[21] Khasawneh, A., Humeidan, A., Alsulaiman, J., Bloukh, S., Ramadan, M.,\& AlShatanawi, T( 2020). Medical Students and COVID-19: Knowledge, Attitudes, and Precautionary Measures. A Descriptive Study from Jordan. Frontiers in Public Health; $8: 253$.

[22] Lazarus JV, Ratzan SC, Palayew A, Gostin LO, Larson HJ, Rabin K, et al.A global survey of potential acceptance of a COVID-19 vaccine. Nat Med. 2020:1-4. Epub 2020/10/22.doi: 10.1038/s41591-020-1124-9. PubMed PMID: 33082575; PubMed Central PMCID: PMCPMC7573523.

[23] Lee ,M., \& You, M.(2020). Psychological and behavioral responses in South Korea during the early stages of coronavirus disease 2019 (COVID-19). International Journal of Environment Research Public Health, 17(9):2977

[24] Li Q. Early Transmission Dynamics in Wuhan, China, of Novel Coronavirus-Infected Pneumonia. N. Engl. J. Med. 2020. [CrossRef].

[25] MacDonald NE. Vaccine hesitancy: Definition, scope and determinants. Vaccine. 2015;33(34):4161-4. doi: https://doi.org/10.1016/j.vaccine.2015.04.036.

[26] MacDonald NE. Vaccine hesitancy: Definition, scope and determinants. Vaccine. 2015;33(34):4161-4. Epub 2015/04/22.doi: 10.1016/j.vaccine.2015.04.036. PubMed PMID: 25896383.

[27] Mbachu, C., Azubuike, C., Mbachu, I., Ndukwu,C., Ezeuko, A, \&Udigwe, IB (2020). COVID-19 infection: Knowledge, attitude, practices, and impact among healthcare workers in a South-Eastern Nigerian state. Journal of Infection in Developing Countries

[28] Mohammed, K., \& Al-Hanaw A (2020). Coronavirus Disease (COVID-19):

Pathophysiology, Epidemiology, Clinical Management and Public Health Response 
African Journal of Biology and Medical Research

ISSN: 2689-534X

Volume 4, Issue 3, 2021 (pp. 17-38)

www.abjournals.org

[29] Nicholas, T., Mandaah, F., Esemu, S., Vanessa, A., Gilchrist, K., \&Vanessa, L. (2020). COVID-19 knowledge, attitudes and practices in a conflict affected area of the South West Region of Cameroon. The Pan African Medical Journal,35(34).

[30] Nishiura H. The Extent of Transmission of Novel Coronavirus in Wuhan, China, 2020. J. Clin. Med. 2020, 9,330. [CrossRef] [PubMed].

[31] Ojo, O., Yalma, R., Daniel, E., Abiodun, P., Bello, A., \&Popoola, IO (2020). Knowledge, Attitude and Willingness of Health Care Workers Towards COVID-19 Preventive Measure in a Tertiary Health Institution in North Eastern Part of Nigeria. Central African Journal of Public Health,6(5):251.

[32] Okorie, N. (2011). Mass Media Strategies for Creating Awareness of Breast Cancer, in Public Knowledge Rural.

[33] Olapegba, P., Ayandele, O., Kolawole, S., Oguntayo, R., Gandi, J., Dangiwa, A., Ottu, I.,\&Iorfa S. (2020). A preliminary assessment of novel coronavirus (COVID-19) knowledge and perceptions in Nigeria. $B M J$.

[34] Omer SB, Yildirim I, Forman HP. Herd Immunity and Implications for SARS-CoV-2 Control.JAMA. 2020;324(20):2095-6. doi: 10.1001/jama.2020.20892.

[35] Pictrow, P., Kincaid, D., Riman, I., and Rimchart, N. (1997) Health Communication Lessons from Family Planning.

[36] Pogue K, Jensen JL, Stancil CK, Ferguson DG, Hughes SJ, Mello EJ, et al. Influences on Attitudes Regarding Potential COVID-19 Vaccination in the United States.Vaccines (Basel). 2020;8(4). Epub 2020/10/08.doi: 10.3390/vaccines8040582. PubMed PMID: 33022917; PubMed Central PMCID: PMCPMC7711655.

[37] Prasad. J., Sewda, A., \&Shiv, D.(2020) Assessing the knowledge, attitude and practices of students regarding the COVID-19 pandemic. Journal of Health Management

[38] Ray M. (2019) Role of Media in Social Awareness. Arabian Journal of Humanities \& Social Sciences, Vol 1 (01), 167-170

[39] Rothe C. Transmission of 2019-nCoV Infection from an Asymptomatic Contact in Germany. N. Engl. J. Med. 2020. [CrossRef].

[40] Roy, D., Tripathy, S., Kar, S., Sharma, N., Verma, S., \& Kaushal V. Study of knowledge, attitude, anxiety \& perceived (2020).Study of knowledge, attitude, anxiety $\&$ perceived mental healthcare need in Indian population during COVID-19 pandemic.Mental healthcare need in Indian population during COVID-19 pandemic.Asian Journal Psychiatric.

[41] Schoch-Spana M, Brunson EK, Long R, Ruth A, Ravi SJ, Trotochaud M, et al. The public's role in COVID-19 vaccination: Human-centered recommendations to enhance pandemic vaccine awareness, access, and acceptance in the United States. Vaccine. 2020. doi: https://doi.org/10.1016/j.vaccine.2020.10.059.

[42] Soola, (2003), The Role of the Media in the Construction of Public Belief and Social Change. (A. Livingstone, Ed.) Journal of Social and Political Reviews, Vol. 2(3), 21-36

[43] Tamam El-Elimata,*, Mahmoud M. AbuAlSamenb, Basima A. Almomanic, Nour A. Al-Sawalhac, and Feras Q. Alalid,e;Acceptance and Attitudes Toward COVID-19 Vaccines: A Cross-Sectional Study from Jordan. medRxivpreprintdoi:https://doi.org/10.1101/2020.12.22.20248676doithis version posted December 24, 2020. ;

[44] Wang C, Horby PW, Hayden FG, etal.A novel coronavirus outbreak of global health concern. Lancet 2020; 395(10223):470-73. [published Online First: 2020/01/28] https://doi.org/10.1016/S0140-6736 (20)30185-9 PMID: 31986257 
[45] Winter, S., Dzombo, M., \&Barchi, F. (2019).Exploring the complex relationship between women's sanitation practices and household diarrhea in the slums of Nairobi: A cross-sectional study. BMC Infectious Diseases, 2019:242.

[46] World Health Organization (WHO). Risk Communication and Community Engagement (RCCE) Action Plan Guidance COVID-19 Preparedness and Response. 16 March 2020. https://www.who.int/docs/ default-source/coronaviruse/covid19-rcce-guidance-finalbrand.pdf

[47] Yanovitzky, H. and Blitz, R. (2000) Development Communication in India: Prospect, Issues and Trends, Global Media journal - Indian edition / December 2011 vol. 2/no.2/ issn 2249-5835 winter issue.

[48] Zhong, B., Luo, W., Li, H., Zhang, Q., Liu, X.,\& Li, W. (2020). Knowledge, attitudes, and practices towards COVID-19 among Chinese residents during the rapid rise period of the COVID-19 outbreak: A quick online cross-sectional survey. International Journal of Biological Science, 16(10):1745-1752.

[49] Zimmer C, Corum J, Wee S-L. Coronavirus vaccine tracker US: The New York Times; 2020 [cited 2020 December 13]. Available from: https://www.nytimes.com/interactive/. 